\title{
CHANGES IN THE EXPORT OF POLISH FOOD INDUSTRY PRODUCTS: ON THE ISSUES OF DOMESTIC AND FOREIGN VALUE ADDED TAX
}

ŁUKASZ AMBROZIAK (PhD)

https://doi.org/10.35945/gb.2017.03.020

Institute of Agricultural and Food Economics - National Research Institute, Poland

KEYWORDS: FOOD INDUSTRY, DOMESTIC VALUE ADDED, FOREIGN VALUE ADDED, EXPORTS, POLAND

\section{INTRODUCTION}

One of the signs of the economic globalisation is the fragmentation of production processes. It means that the manufacture of processed goods involves producers from various countries, importing raw materials, materials and semi-finished products, carrying out their further processing and exporting them as products, frequently used in other countries as components and semi-finished products for downstream producers (OECD, 2013). Before it is intended for final consumption the end product has repeatedly crossed the borders of a number of countries and contains value added by many manufacturers. This phenomenon challenged the usefulness of traditional calculations of the value of international trade flows in gross terms, i.e. measuring the value of final goods crossing the borders of specific customs areas, since it led to overstatements of the trade value. The result is the development of world input-output tables, serving to generate trade statistics in value added terms which take account of the contribution of particular countries to the creation of value added and eliminate the multiple calculation in trade of components, first separately (as intermediate goods) and then as parts of final goods (UNCTAD 2013).

This phenomenon of fragmentation of production processes concerns also the food industry in Poland and has impact on exports of food industry products. Thus, the aim of the paper is to present changes in Polish exports of food industry products in 2000-2014 using trade statistics in value added terms. They allow to decompose gross exports by the origin of the value added content, i.e. domestic and foreign inputs.

The structure of the paper is as follows. The paper begins with a brief overview of the literature concerning the concept of value added in trade. Next, the research method and data are presented. The main part of the paper is an analysis of changes in Polish exports of food industry products in terms of domestic and foreign inputs. Also, comparison of food industry with other manufacturing sectors is included. Finally, conclusions are drawn.

\section{THE APPLICATION OF INPUT-OUTPUT TABLES IN THE MEASUREMENT OF VALUE ADDED IN TRADE}

An input-output table contains a statistical description of production activities in a particular industry of the economy concerned over a specified period (usually one year). In other words, such a table provides information on the creation and distribution of the product in the economy, with a special focus on the relationships between production industries at intermediate stages of manufacturing (Leontief 1986). Initially, input-output tables were designed as models of the whole economies, but as early as the mid-1950s such tables began to include linkages between a number of countries and regions. One example can be the GTAP (Global Trade Analysis Project) launched in the early 1990s. This project (still in progress) aims to build a quantitative general equilibrium model for the analysis of the world economy processes.

The development of international input-output tables is difficult and time-consuming as it requires the 'alignment' of national input-output tables with data on bilateral trade of specific countries. It is also necessary to properly assign foreign value added to the initial countries of origin, which is a complex task due to the high degree of the fragmentation of production networks and the difficult separation of value added (Wiedmann et al. 2011). For example, intermediate goods shipped by a country abroad may return to it as re-imports of goods processed to a specific extent. In addition, some of the imports from the last supplier country may originate in third countries.

A simplified schema of an international input-output table (for three countries and one economic sector), presented in Fig. 1, reflects the essence of such a table. Specific rows of the table provide information on the directions of export of goods and services produced in a country. At the same time, specific columns allow to determine the origin of goods and services absorbed in the production of a country (intermediate consumption) as well as for consumption (final demand). For example, the row for Country 1 shows the share of the output of intermediates absorbed in the country and that exported to Countries 2 and 3 as well as the share of the output of final goods consumed in the country and that exported to Countries 2 and 3 . In addition, the table contains information on imports of intermediates/ final goods from Countries 2 and 3 absorbed in production/ consumed in Country 1.

\section{THE RESEARCH METHOD}

This study was carried out with the use of data from the World Input-Output Database (WIOD Release 2016), containing world input-output tables for the years 2000-2014. On the basis of the above-mentioned tables, using the input-output (IO) model, appropriate calculations were made. The basic equation is as follows: 


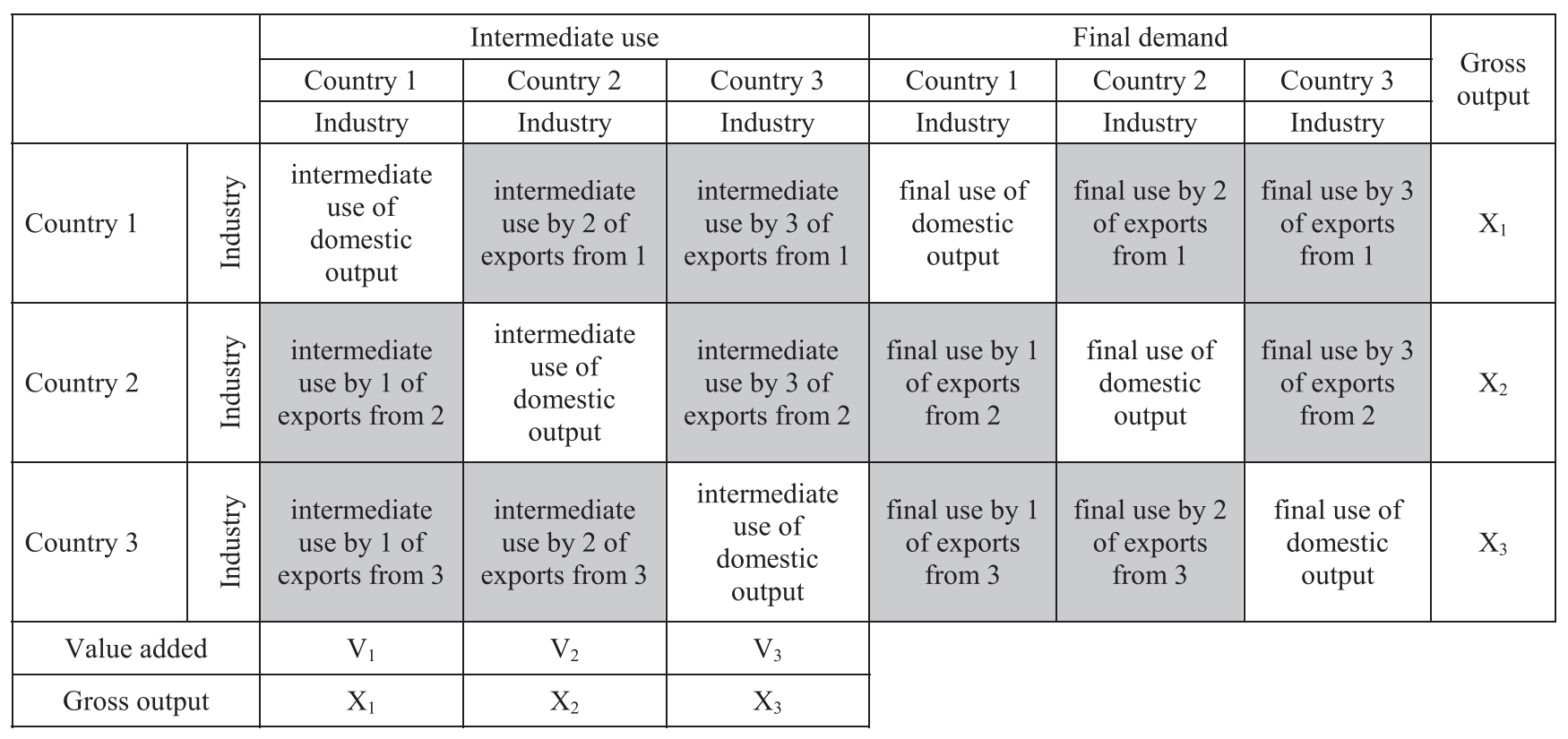

Fig. 1. International input-output table schema Source: Own study.

where:

$$
x=A x+f=L f,
$$

$\mathbf{x}$ denotes the vector of gross output,

A denotes the matrix of technical input-output coefficients (costs),

$f$ denotes the vector of final output,

$\mathbf{L}=(\mathbf{I}-\mathbf{A})^{-1}$ denotes the matrix of material-intensity (or additional demand) coefficients, also referred to as the Leontief inverse (and $\mathrm{I}$ is a unit matrix).

In order to decompose exports of a country by origin of value added, the value added trade flow matrix $\mathbf{T}$ was used, in the following form (Stehrer 2012, 2013; Stehrer and Foster 2012):

$$
\mathrm{T}=\mathrm{vLe},
$$

where:

v denotes the $2464 \times 2464$ matrix containing on the diagonal value added coefficients for 44 countries and 56 industries.

L denotes the $2464 \times 2464$ Leontief inverse matrix,

e denotes the $2464 \times 2464$ matrix containing on the diagonal exports value of 44 countries and 56 industries.
Assuming that the world economy consists of 3 economies (superscripts indicate countries) with 2 sectors each (subscripts indicate sectors), the value added trade flow matrix T will be as follows:

This matrix allows to assess both the origin of the value added content of exports of each country and industry as well as the distribution of the value added across countries. In order to determine the composition of exports by the country of the origin of value added, we need to look at the columns of the above matrix, whereas the directions of the distribution of value added in exports of countries of destination are shown in the rows.

The first column indicates the value of the exports of country 1 in sector 1 . The exports could be split into the value which is added in sector $1\left(v_{1}^{1} L_{1}^{1} e_{1}^{1^{*}}\right)$, and the value added in sector $2\left(v_{2}^{1} L_{2}^{1} e_{1}^{1^{*}}\right)$, and similarly for foreign value added originated in country 2 (in sector $1-v_{1}^{2} L_{1}^{2} e_{1}^{1^{*}}$ and in sector $2-v_{2}^{2} L_{2}^{2} e_{1}^{1^{*}}$ ) and in country 3 (in sector $1-v_{1}^{3} L_{1}^{3} e_{1}^{1^{*}}$ and in sector $\left.2-v_{2}^{3} L_{2}^{3} e_{1}^{1^{*}}\right)$. Similar interpretations would hold for the other countries and sectors, respectively.

$$
\mathrm{T}=\left(\begin{array}{cccccc}
v_{1}^{1} L_{11}^{11} e_{1}^{1^{*}} & v_{1}^{1} L_{12}^{11} e_{2}^{1^{*}} & v_{1}^{1} L_{11}^{12} e_{1}^{2^{*}} & v_{1}^{1} L_{12}^{12} e_{2}^{2^{*}} & v_{1}^{1} L_{11}^{13} e_{1}^{3^{*}} & v_{1}^{1} L_{12}^{13} e_{2}^{3^{*}} \\
v_{2}^{1} L_{21}^{11} e_{1}^{1^{*}} & v_{2}^{1} L_{22}^{11} e_{2}^{1^{*}} & v_{2}^{1} L_{21}^{12} e_{1}^{2^{*}} & v_{2}^{1} L_{22}^{12} e_{2}^{2^{*}} & v_{2}^{1} L_{21}^{13} e_{1}^{3^{*}} & v_{2}^{1} L_{22}^{13} e_{2}^{3^{*}} \\
v_{1}^{2} L_{11}^{21} e_{1}^{1^{*}} & v_{1}^{2} L_{12}^{21} e_{2}^{1^{*}} & v_{1}^{2} L_{11}^{22} e_{1}^{2^{*}} & v_{1}^{2} L_{12}^{22} e_{2}^{2^{*}} & v_{1}^{2} L_{11}^{23} e_{1}^{3^{*}} & v_{1}^{2} L_{11}^{23} e_{2}^{3^{*}} \\
v_{2}^{2} L_{21}^{21} e_{1}^{1^{*}} & v_{2}^{2} L_{22}^{21} e_{2}^{1^{*}} & v_{2}^{2} L_{21}^{22} e_{1}^{2^{*}} & v_{2}^{2} L_{22}^{22} e_{2}^{2^{*}} & v_{2}^{2} L_{21}^{23} e_{1}^{3^{*}} & v_{2}^{2} L_{11}^{23} e_{2}^{3^{*}} \\
v_{1}^{3} L_{11}^{31} e_{1}^{1^{*}} & v_{1}^{3} L_{12}^{31} e_{2}^{1^{*}} & v_{1}^{3} L_{11}^{32} e_{1}^{2^{*}} & v_{1}^{3} L_{12}^{32} e_{2}^{2^{*}} & v_{1}^{3} L_{11}^{33} e_{1}^{3^{*}} & v_{1}^{3} L_{12}^{33} e_{2}^{3^{*}} \\
v_{2}^{3} L_{21}^{31} e_{1}^{1^{*}} & v_{2}^{3} L_{22}^{31} e_{2}^{1^{*}} & v_{2}^{3} L_{21}^{32} e_{1}^{2^{*}} & v_{2}^{3} L_{22}^{32} e_{2}^{2^{*}} & v_{2}^{3} L_{21}^{33} e_{1}^{3^{*}} & v_{2}^{3} L_{22}^{33} e_{2}^{3^{*}}
\end{array}\right)
$$


In the next part of the paper, the results of the decomposition of Polish exports of food industry products are presented. Food industry products are understood as products of three processing branches according to the International Standard Industrial Classification (ISIC) Rev. 4: C10. Manufacture of food products, C11. Manufacture of beverages, C12. Manufacture of tobacco products.

Two databases containing comprehensive world input-output tables were made available in 2012-2013. In May 2012, the implementation of the WIOD (World Input-Output Database) project was completed, resulting in the creation of a database containing, inter alia, a set of world input-output tables by industry of the economy (Timmer et al. 2015). In January 2013, the Organisation for Economic Co-operation and Development together with the World Trade Organisation presented another database, Trade in Value Added - TiVA. Its undoubted merit is that it contains computed indicators of the share of value added in trade flows.

The above-mentioned databases were updated several times. The WIOD Release 2016 (updated in November 2016) covers 43 countries, including 28 EU Member States and 13 other major economies such as: the USA, Canada, Brazil, Mexico, China, India, Japan, South Korea, Norway, Switzerland, Australia, Taiwan, Turkey, Indonesia and Russia. The database contains data for 2000-2014 (15 years) for 56 industries by 56 industries (Timmer et al. 2016). In turn, the 2016 edition of the TiVA database provides indicators for 63 economies covering OECD, 28 EU Member States, G20, most East and Southeast Asian economies and a selection of South American countries. 34 unique industrial sectors are represented, including 16 manufacturing and 14 services sectors. Indicators are provided for all years from 1995 to 2011 - OECD 2016

In addition to the two above-mentioned databases, international input-output tables are also contained in databases such as the Global Trade Analysis Project (GTAP), the Eora multi-region input-output tables (MRIO), the multi-regional input-output tables of the Asian Development Bank (ADB-MRIO) and the Asian International Input-Output Tables of the IDE-JETRO (AIIOTs).

\section{CHANGES IN POLISH EXPORTS OF FOOD INDUSTRY PRODUCTS}

In 2000-2014, Polish exports of food industry products went up dynamically, especially after Poland's accession to the European Union (1 May 2004). In 2014, Polish food indus- try exports were USD 19.4 billion, i.e. more than eight times the 2000 value (Fig. 2). During Poland's membership of the EU, the most important determinants of the development of foreign trade in food products undoubtedly included full opening of the markets and free trade between Poland and the EU Member States. However, it would have been impossible without good preparation of the Polish food economy for EU membership, preceded by structural changes in the food industry during economic transition. There were several crucial factors (Szczepaniak 2014; Ambroziak 2015). Firstly, in the period immediately preceding EU accession, producers implemented a great number of investment projects adapting their plants to the EU standards. Secondly, Polish producers proved to know the EU market well and to be active market players. Thirdly, other important determinants comprised the inflow of foreign direct investment and foreign strategic investors' entering Polish enterprises. A number of Polish businesses became subsidiaries of foreign corporations, automatically included in processes of globalisation and international specialisation. Fourthly, trade in food industry products also developed as a result of obtaining considerable EU funds, both in the pre- and post-accession periods.

The factors described above contributed to an increased role of the food industry in the Polish economy, including in foreign trade. In the period covered, the share of food industry products in total exports of manufactures augmented more than by a factor of 1.5 - from $7.6 \%$ in 2000 to $12.2 \%$ in 2014 (Fig. 2).

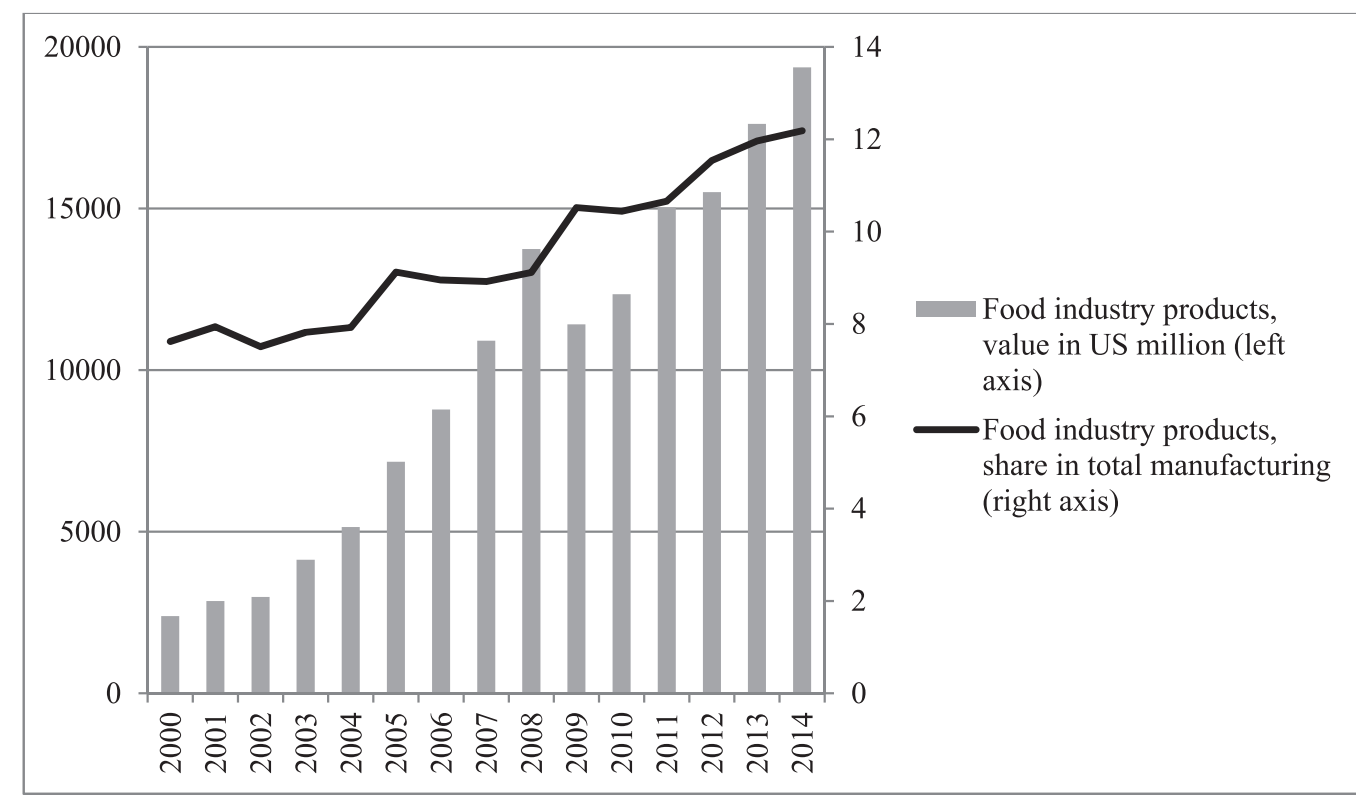


domestic value added content (value added created in Poland) rose by a factor of 7.3.

A higher growth rate of foreign content of exports than that of domestic content meant a fall in the proportion of domestic value added in Polish exports of food industry products (Fig. 3). In the period under analysis, that share declined by 9.6 pps (from $83.7 \%$ in 2000 to $74.1 \%$ in 2014). Therefore, that was also the growth in the share of foreign value added content of Polish food industry exports (from 16.3\% to $25.9 \%$ ). In other words, it means that exports of products manufactured in the Polish food industry to a greater degree relied on imported raw materials and semi-finished goods. The foreign content of exports gained in importance especially at the turn of the 2000s and the 2010s. In 2009-2011, the share of foreign value added content of Polish exports of food industry products went up from $20.1 \%$ to $26.5 \%$, i.e. by over 6 pps.

ented towards stimulating exports, primarily develop thanks to relatively lower production costs (e.g. the remuneration of labour, materials, energy) and lower margins in Polish manufacturing, which points to its competitive advantages in price and cost terms (Szczepaniak 2014).

The share of foreign value added varied widely between specific food industries. Foreign value added content of exports was the most significant in industries where output intended for export relied on raw materials and semi-finished products imported from abroad (Szczepaniak 2017). It concerned, inter alia, fish processing (imports of raw fish), the confectionery industry (imports of cocoa solids and fats) as well as the processing of tea and coffee. For example, Poland became specialised in exporting smoked salmon (mostly to Germany) based on raw salmon imported from abroad, mainly from Norway. At the same time, foreign value added played the least important role in sectors where export-oriented production largely relied on domestic raw materials and semi-finished products. It concerned industries such as the dairy industry, the processing of fruit and vegetables, the milling and baking industries. The low import intensity of production in those industries resulted from the availability of domestic raw materials and semi-finished products and the need to locate processing plants near the place of production on account of the perishability of raw materials.

Against the backdrop of other economic sectors, the food industry was characterised by a relatively high share of domestic value added content of food industry exports (Fig. 4). In 2014,

Figure 3: Decomposition of Polish food industry exports by value added (in \%)

Source: Own calculations based on WIOD Release 2016.

In the period of Poland's EU membership, the manufacture of food products became more dependent on the supply of imported raw materials, which reflected the inclusion of raw material procurement in the fast-developing internationalisation of the Polish food economy. Nevertheless, food production in Poland continued to mostly rely on raw materials from domestic agriculture.

Annually increasing imports are supplementary to the supply of domestic raw materials (during their shortages) or enhance it (by adding raw materials originating in other climatic zones) on the one hand, and - on the other hand - they are processing in nature as some raw materials are processed by domestic food industry enterprises and subsequently re-exported (in this context, they are beneficial to both enterprises and the economy as a whole). Processing imports, ori- higher shares of domestic value added content of exports were only found in products of five sectors of the economy, i.e. forestry and logging, mining and quarrying, basic pharmaceutical products, crop and animal production, wood and products of wood as well as services (understood as the sum of all types of services). Therefore, those were mainly economic sections which sourced raw materials or produced raw material-intensive goods. A high share of domestic value added content of exports resulted from the fact that the provision of services offered fewer fragmentation options than the manufacture of products. Simultaneously, the domestic component was the lowest in exports of products of food industries actively participating in production fragmentation processes, thus strongly integrated into global value chains. In 2014, domestic value added only accounted for slightly more than $40 \%$ of exports of computer, electronic and optical products and for about half of exports of coke and refined petroleum products, motor vehicles, trailers and semi-trailers as well as of basic metals. 


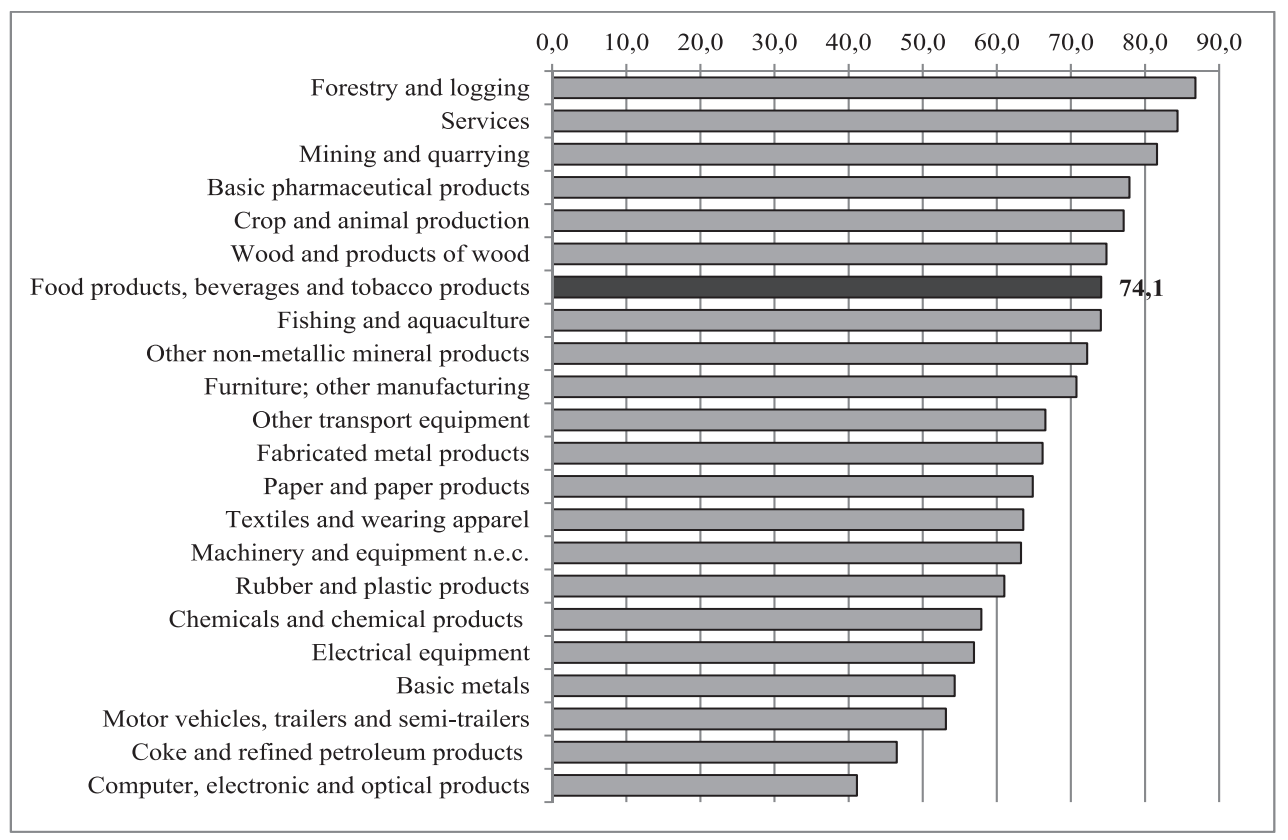

Figure 4: Share of domestic value added content of Polish exports by economic activity (in \%) Source: Own calculations based on WIOD Release 2016.

Between 2000 and 2014, all sections of the Polish economy experienced a fall in the share of domestic value added content of exports. The food industry ranked more or less in the middle. The most abrupt decline in the proportion of domestic value added content of exports concerned manufacturing divisions actively participating in production fragmentation processes. The share of domestic value added content of exports of computer, electronic and optical products dropped by as much as 22.1 pps in the period covered. A distinct decrease in the domestic component was also noted in exports of products such as: electrical equipment, textiles and wearing apparel, basic metals, chemicals and chemical products, rubber and plastic products, motor vehicles. The least significant fall in the share of domestic value added content was found in exports of services as well as of production sectors such as: other transport equipment, forestry and logging, mining and quarrying, crop and animal production, other non-metallic mineral products.

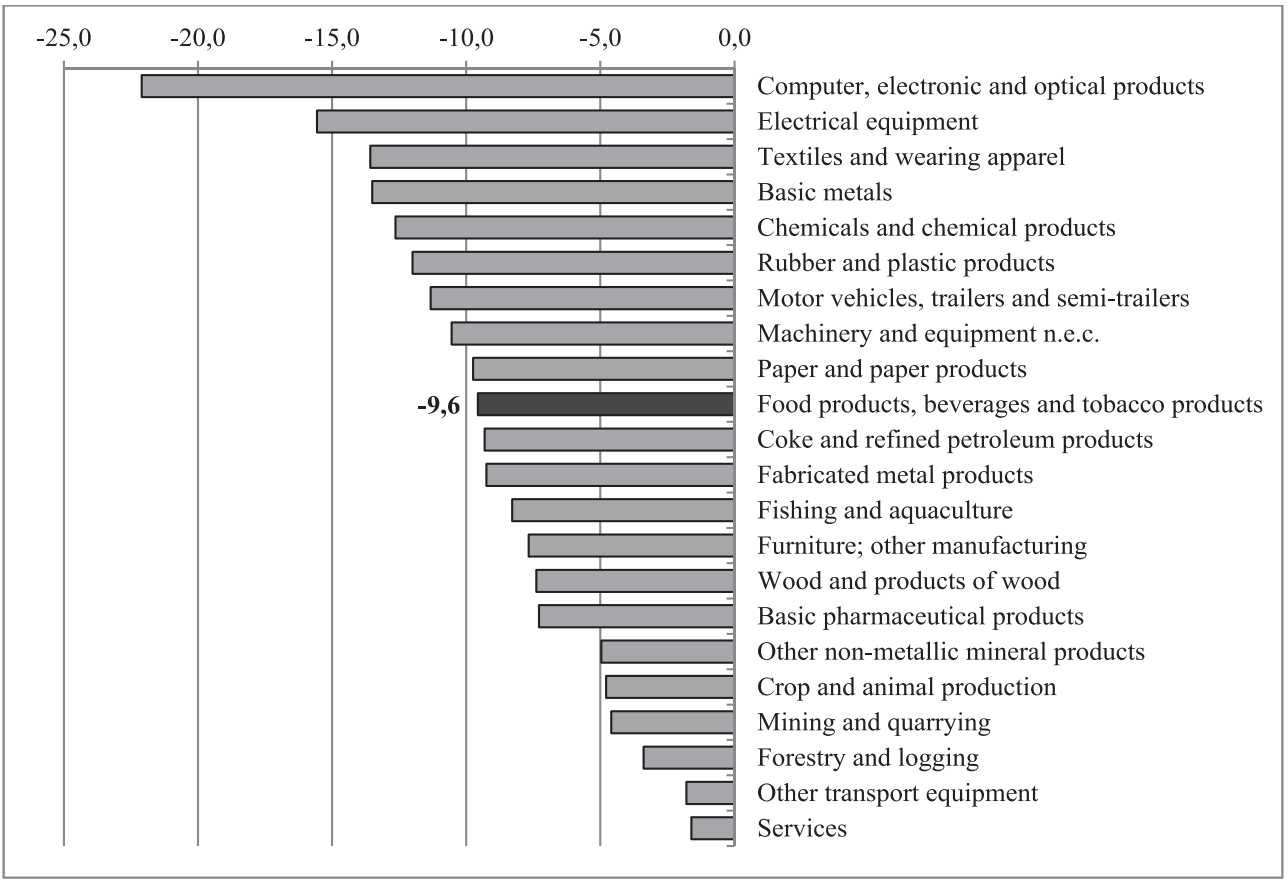

Figure 5: Changes in the share of domestic value added content of Polish exports by economic activity (in pps) Source: Own calculations based on WIOD Release 2016. 
In 2014, in comparison with other European Union Member States, Poland ranked among countries characterised by relatively high domestic value added content of food industry exports (Fig. 6). Only seven EU Member States outperformed Poland in this respect: Romania, Greece, the United Kingdom, France, Spain, Italy and Germany. With the exception of the first two countries, those were the EU's largest food exporters.
At the same time, the lowest domestic value added content was found in Irish exports of food industry products. In 2014, value added created in Ireland represented a mere $43.7 \%$ of those exports, whereas the remaining share was value added generated abroad. In addition, low proportions of domestic value added characterised Belgium and the Netherlands (major food exporters in the EU) and Denmark.

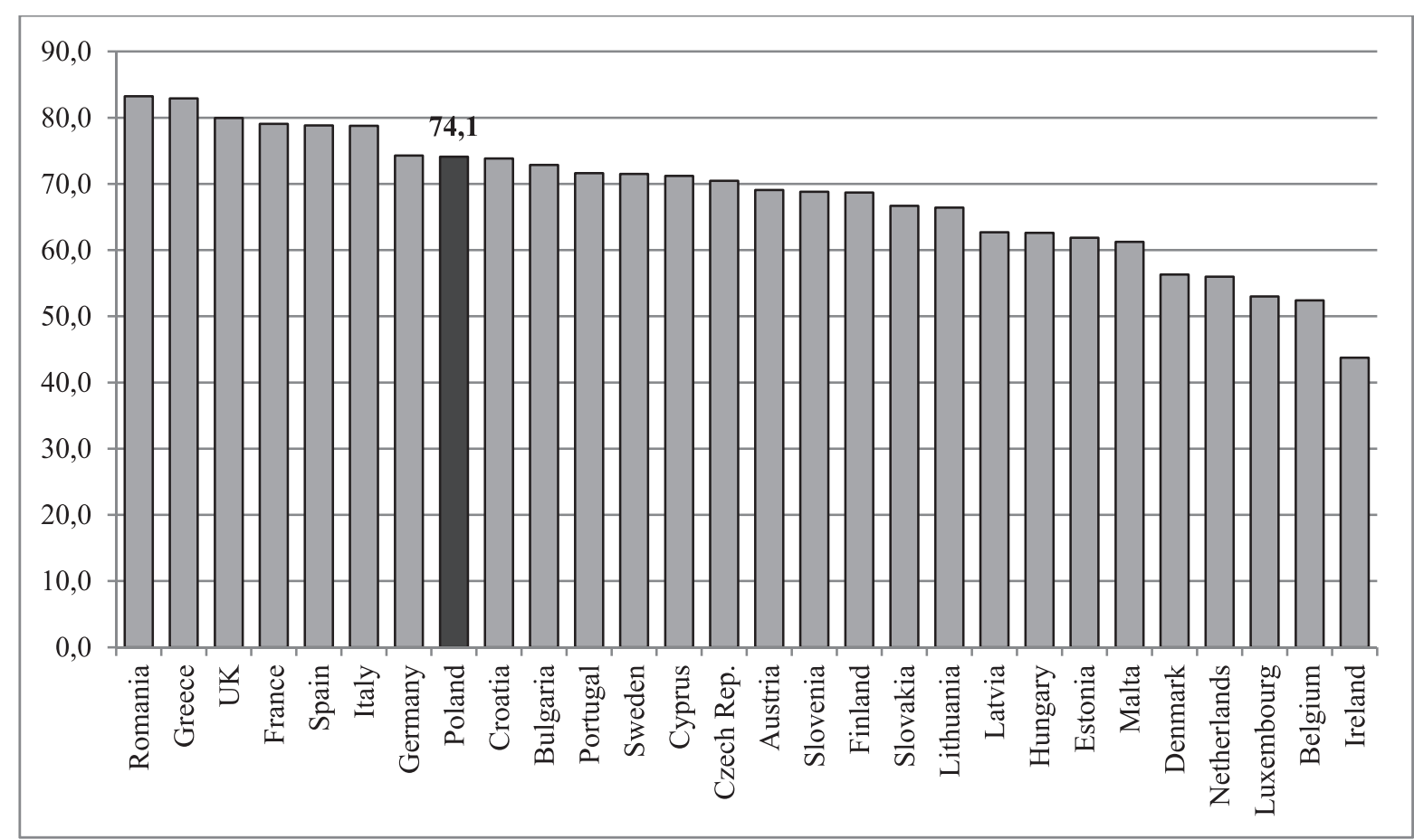

Figure 6: Share of domestic value added content of food industry exports in the EU Member States (in \%) Source: Own calculations based on WIOD Release 2016.

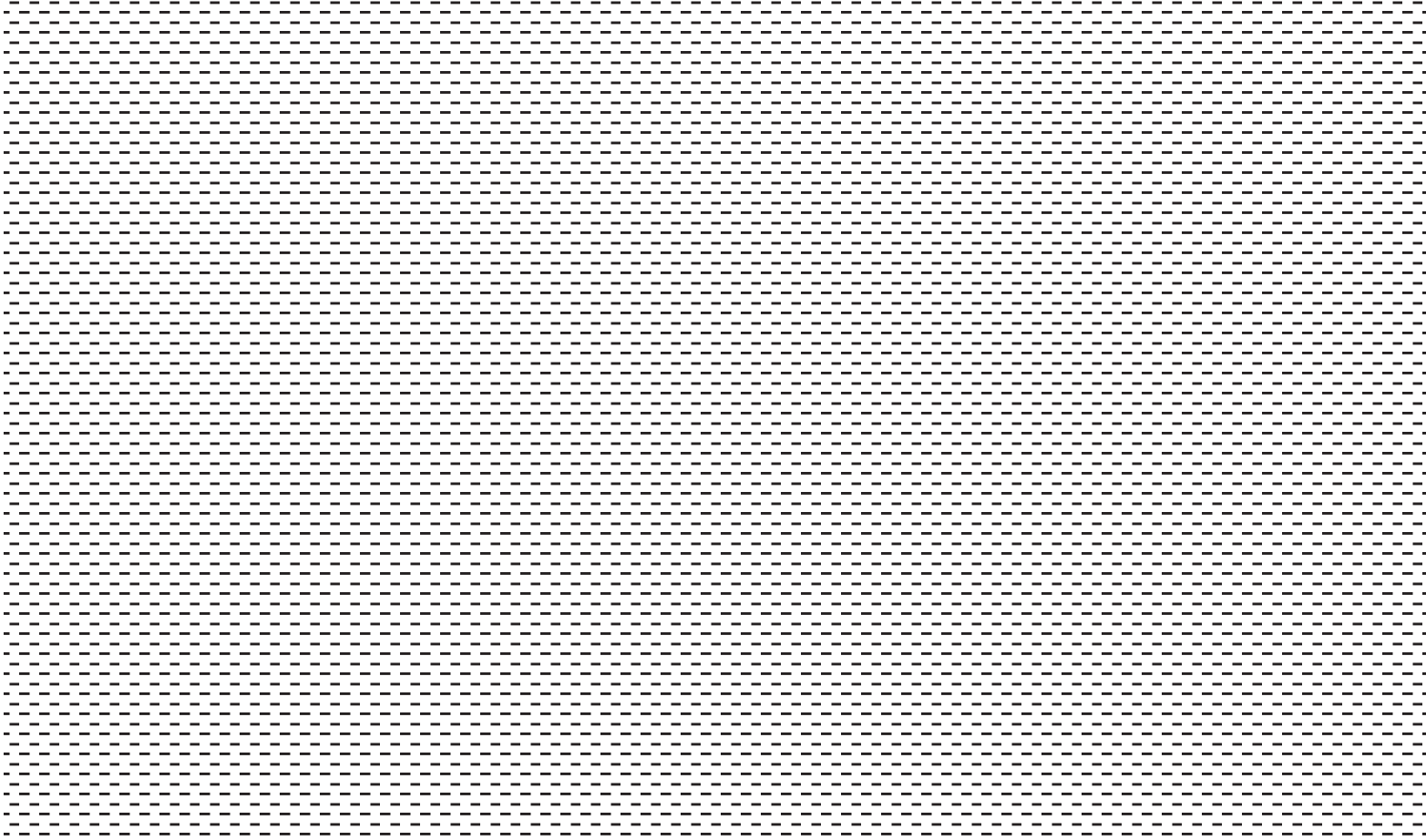

Figure 7: Changes in the share of domestic value added content of food industry exports in the EU Member States in 2000-2014 (in \%) Source: Own calculations based on WIOD Release 2016. 
Except for Croatia, in 2000-2014 there was a decline in the share of domestic value added content of food industry exports of other EU Member States (Fig. 7). In terms of rate of the decrease, Poland ranked seventh among the EU Member States. Steeper falls in the domestic component than in Poland were noted in Ireland, Denmark, Belgium, the Netherlands, Latvia and Finland.

The created matrix of value added flows also allows to decompose the foreign value added content of Poland's exports of food industry products by country of the origin of foreign value added. In 2000-2014, certain changes occurred.

There was an increase in the share of all the countries and groups of countries distinguished in Figure 8 in the foreign value added content of Polish exports of food industry products. The most significant growth concerned the share of other countries (up by $2.2 \mathrm{pps}$ ), mostly due to rising imports of raw salmon from Norway. The proportion of content imported from Germany went up by 2 pps, whereas that of

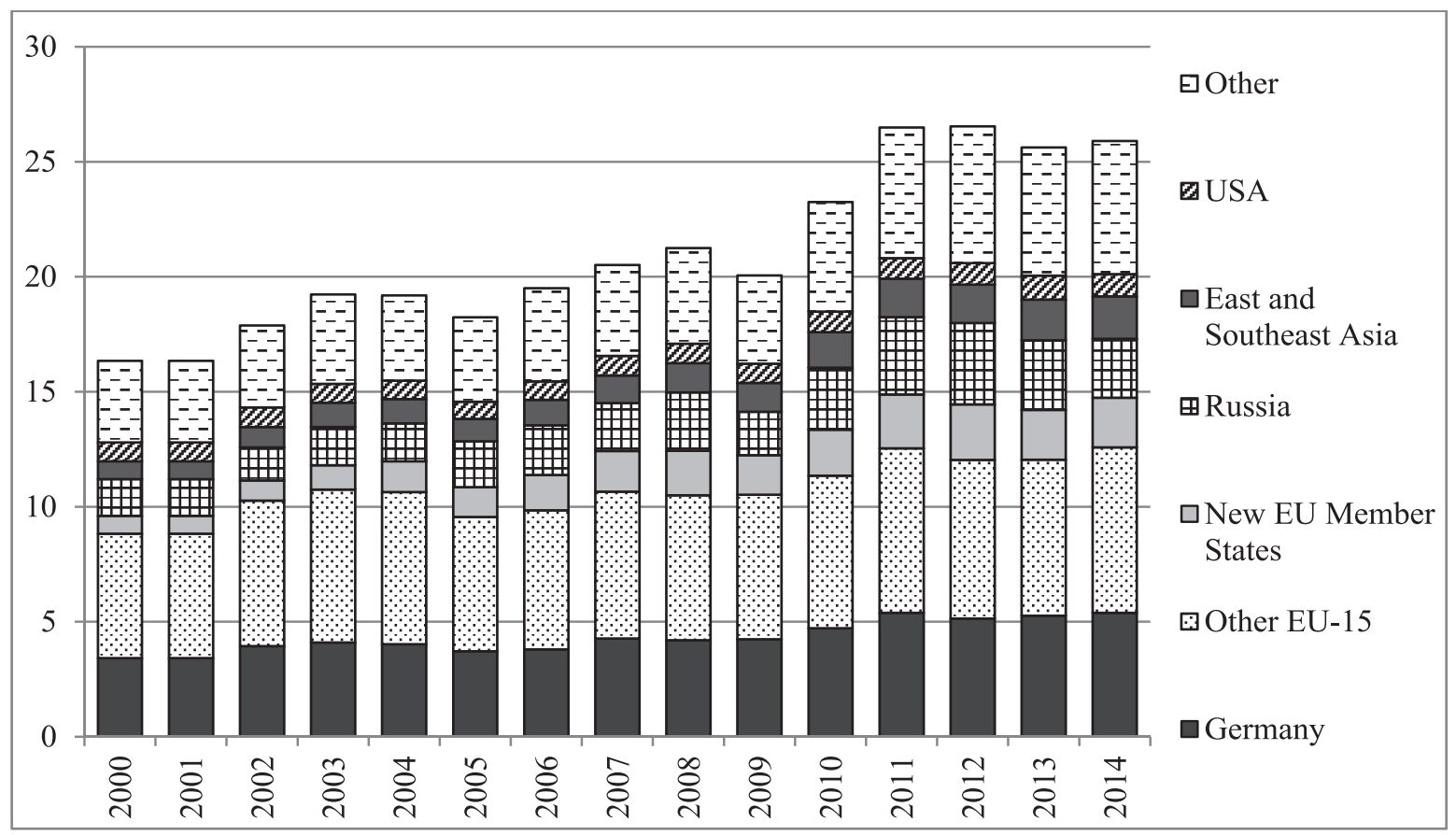

Figure 8: Foreign value added content of Polish food industry exports by country of origin (in \% of food industry exports) Source: Own calculations based on WIOD Release 2016.

foreign value added from other EU-15 countries augmented by 1.8 pps (mainly on account of growing imports of live pigs and pigmeat from Denmark). Other countries contributing to greater foreign value added content of Polish food industry exports included the new EU Member States (an increase in the share of those exports by $1.1 \mathrm{pps}$ ), East and South-East Asia (up by 1.1 pps, mostly China) and Russia (up by 1.0 pp, mainly as a result of rising imports of energy fuels).

In 2014, the most foreign value added content of Polish exports of food industry products originated in Germany and other EU-15 countries. The value added created in the countries in question accounted for $5.4 \%$ and $7.2 \%$, respectively, of Polish food industry exports. The share of value added from the new EU Member States, Russia as well as from East and South-East Asia was ca. $2 \%$ of those exports each, whereas the United States represented 1\%. Other countries accounted for nearly $6 \%$ of Poland's food industry exports.

\section{CONCLUSIONS}

The making available in the 2010s of databases containing world input-output tables (e.g. WIOD) was a significant advancement in research on international trade. It allowed to create a matrix of world value added flows in gross exports, and, as a consequence, to decompose Polish gross exports of food industry products by the origin of the value added content, that is in domestic and foreign inputs.

According to the investigation carried out, in 2000-2014 the share of domestic value added content of Polish gross exports of food industry products dropped by nearly $10 \mathrm{pps}$. In 2014 , slightly more than $74 \%$ of those exports was value added created in Poland, whereas foreign value added accounted for the remaining almost $26 \%$. In comparison with other economic sectors, the share of domestic value added content of Polish exports of food industry products was relatively high. In this respect, the figure for Poland was also above the EU average.

Such a situation is beneficial to the Polish economy. In the case of large domestic inputs in Polish exports, the components of value added, i.e. wages, taxes on production and imports less subsidies, and the gross operating surplus, remain in Poland. Furthermore, only domestic value added of an industry, thus domestic value added content of exports, contributes to the overall gross domestic product of the country. 


\section{REFERENCES:}

1. Ambroziak, Ł. (2015). The Competitive Position of the New Member States in Trade in Food Industry Products. In Proceedings of the Competitiveness of Agro-Food and Environmental Economy (CAFEE'2015). Bucharest: Bucharest Academy of Economic Studies.

2. Leontief, W. (1986). Input-Output Economics. New York: Oxford University Press.

3. OECD (2013). Interconnected Economies: Benefiting from Global Value Chains. OECD Publishing.

4. OECD (2016). Trade in Value Added Database.

5. Stehrer, R. (2012). Trade in Value Added and the Value Added in Trade. wiiw Working Paper, 81.

6. Stehrer, R. (2013). Accounting Relations in Bilateral Value Added Trade. WIIW Working Papers, 101.

7. Stehrer, R., Foster, N. \& de Vries, G. (2012). Value added and Factors in Trade: A comprehensive approach. wiiw Working Paper, 80.

8. Szczepaniak, I. (2017). Krajowe i importowane surowce w produkcji żywności w Polsce [The use of domestic and imported raw materials in food production in Poland]. Przemysł Spożywczy, 4, 2-5.

9. Szczepaniak, I. ed. (2014). Assessment of the competitiveness of Polish food producers in the European Union. "Multi-Annual Programme 2011-2014", No 126.1, Warsaw: IAFE-NRI.

10. Timmer, M. P., Dietzenbacher, E., Los, B., Stehrer, R. \& de Vries, G. J. (2015). An Illustrated User Guide to the World InputOutput Database: the Case of Global Automotive Production. Review of International Economics, 23, 575-605.

11. Timmer, M. P., Los, B., Stehrer, R. \& de Vries, G.J. (2016). An Anatomy of the Global Trade Slowdown based on the WIOD 2016 Release. GGDC research memorandum number 162, University of Groningen.

12. UNCTAD (2013). World Investment Report. New York and Geneva.

13. Wiedmann, T., Wilting, H.C., Lenzen, M., Lutter, S. \& Palm,V. (2011). Quo Vadis MRIO? Methodological, Data and Institutional Requirements for Multi-Region Input-Output Analysis. Ecological Economics, 70(11), 1937-1945. 


\section{CHANGES IN THE EXPORT OF POLISH FOOD INDUSTRY PRODUCTS: ON THE ISSUES OF DOMESTIC AND FOREIGN VALUE ADDED TAX}

tUKASZ AMBROZIAK (PhD)

https://doi.org/10.35945/gb.2017.03.020

Institute of Agricultural and Food Economics - National Research Institute, Poland

KEYWORDS: FOOD INDUSTRY, DOMESTIC VALUE ADDED, FOREIGN VALUE ADDED, EXPORTS, POLAND

\section{SUMMARY}

The aim of the paper is to present changes in Polish exports of food industry products in 2000-2014 using trade statistics in value added terms. They allow to decompose gross exports by the origin of the value added content, i.e. domestic and foreign inputs. For this purpose, the World Input-Output Database (WIOD Release 2016) was used to create a matrix of value added flows in the world economy.
According to the investigation carried out, in 2000-2014 the share of domestic value added content of Polish gross exports of food industry products dropped by nearly $10 \mathrm{pps}$. In 2014 , slightly more than $74 \%$ of those exports was value added created in Poland, whereas foreign value added accounted for the remaining almost $26 \%$. In comparison with other economic sectors, the share of domestic value added content of Polish exports of food industry products was relatively high. In this respect, the figure for Poland was also above the EU average. 